\title{
Splenic Diffuse Red Pulp Small B-Cell Lymphoma
}

National Cancer Institute

\section{Source}

National Cancer Institute. Splenic Diffuse Red Pulp Small B-Cell Lymphoma. NCI

Thesaurus. Code C80309.

An uncommon, indolent B-cell non-Hodg kin lymphoma composed of small B-

lymphocytes involving the red pulp of the spleen, bone marrow, and peripheral blood.

Patients often have massive splenomegaly. The peripheral blood examination reveals villous lymphocytes. 